\title{
IN SITU DETECTION OF CELL WALL POLYSACCHARIDES IN SITKA SPRUCE (PICEA SITCHENSIS (BONG.) CARRIĖRE) WOOD TISSUE
}

\author{
Clemens Altaner ${ }^{\mathrm{a} *}$, J. Paul Knox ${ }^{\mathrm{b}}$ and Michael C. Jarvis ${ }^{\mathrm{a}}$ \\ Wood cell wall polysaccharides can be probed with monoclonal \\ antibodies and carbohydrate-binding modules (CBMs). Binding of \\ monoclonal antibodies to $\beta-1-4-x y l a n, \beta-1-4-m a n n a n, \beta-1-3-g l u c a n$, and \\ $\alpha-1-5$-arabinan structures were observed in native Sitka spruce (Picea \\ sitchensis (Bong.) Carrière) wood cell walls. Furthermore CBMs of \\ different families, differing in their affinities for crystalline cellulose (3a) \\ and amorphous cellulose (17 and 28), were shown to bind to the native \\ wood cell walls with varying intensities. Resin channel forming cells \\ exhibited an increased $\beta-1-4-x y l a n$ and a decreased $\beta-1-4-m a n n a n$ \\ content. Focusing on severe compression wood (CW) tracheids, $\beta-1-3-$ \\ glucan was found towards the cell lumen. In contrast, $\alpha-1-5$-arabinan \\ structures were present in the intercellular spaces between the round \\ tracheids in severe $\mathrm{CW}$, highlighting the importance of this polymer in \\ cell adhesion.
}

Keywords: $\alpha$-1-5-Arabinan, Carbohydrate-binding module (CBM), Cellulose, $\beta$-1-3-Glucan, Immunofluorescence, $\beta$-1-4-Mannan, Monoclonal antibody, Sitka spruce (Picea sitchensis (Bong.) Carrière), $\beta-1-4-X y l a n$

Contact information: a: Chemistry Department, University of Glasgow, Glasgow G12 8QQ, Scotland, UK, b: Centre for Plant Sciences, University of Leeds, Leeds LS2 9JT, England, UK; *Corresponding Author: C.Altaner@chem.gla.ac.uk

\section{INTRODUCTION}

The chemical composition of wood varies not only at the tissue level between wood types but also at the cellular level between cell wall layers. Cell wall components at these levels determine not only the unique mechanical properties of certain wood types but also their chemical reactivity and accessibility to pulping and bleaching agents. The analysis of the chemical wood structure at cellular levels is difficult to achieve. Although advances have been made in the miniaturisation of classical wet-chemical wood analysis, their capacity for spatial resolution is not adequate for investigations at the cellular level (Dahlman et al. 2000; Pranovich et al. 2006). Infrared micro-spectroscopy has the potential to determine the chemical wood composition on the cellular level (Hori and Sugiyama 2003; Dokken et al. 2005). Unfortunately, spectroscopic techniques only yield a limited amount of structural information on the polysaccharides present.

Antibody labelling of plant cell wall polysaccharides has a long history of successful use on primary cell walls (Vreeland 1970), and a wide range of monoclonal antibodies directed to cell wall polymers is now available (Knox 1997). Another type of molecular probe recently used for the detection of polysaccharides in plant cell walls is carbohydrate-binding modules (CBMs) (Din et al. 1991; Taylor et al. 1996; McCartney et

Altaner et al. (2007). "In Situ Detection of Polysaccharides," BioResources 2(2), 284-295. 284 
al. 2004; McCartney et al. 2006; Blake et al. 2006; Filonova et al. 2007). CBMs are classified into families (http://afmb.cnrs-mrs.fr/CAZY/ (Coutinho and Henrissat 1999)), which display different affinities to cell wall polysaccharide structures such as amorphous or crystalline cellulose. Recombinant his-tagged forms of CBMs can be used as selective probes in a manner similar to that used for monoclonal antibodies (McCartney et al. 2004).

Apart from the use of molecular probing techniques for cell wall polysaccharides in differentiating vascular wood tissue (Baba et al. 1994; Guglielmino et al. 1997; Ermel et al. 2000; Maeda et al. 2000; Samuels et al. 2002; Lafarguette et al. 2004), some reports of their application towards mature wood tissues or processed wood products like pulp can be found (Duchesne et al. 2003; Hafrén and Daniel 2003; Hildén et al. 2003; Lappalainen et al. 2004; Brändström et al. 2005; Hafrén 2005; Daniel et al. 2006; Filonova et al. 2007; Altaner et al. 2007). Here we report the potential of molecular probes, which have up to now not been applied to wood, to locate cell wall polysaccharides in untreated Sitka spruce (Picea sitchensis (Bong.) Carrière) crosssections.

\section{EXPERIMENTAL}

Anti-mouse-IgG FITC, anti-rat-IgG FITC, anti-rabbit-IgG FITC, and anti-mouseHis were obtained from Sigma. The $\beta-1-3$-glucan and $\beta-1-4-$ mannan antibodies were obtained from Biosupplies Australia. Details of the anti- $\alpha-1-5$-arabinan monoclonal antibody LM6 (Willats et al. 1998), anti- $\beta-1-4-x y l a n$ LM11 (McCartney et al. 2005), and the microbial CBMs designated CBM3a (Clostridium thermocellum), CBM17 (Clostridium cellulovorans), and CBM28 (Bacillus sp. 1139) have been described elsewhere (Carrard et al. 2000; Boraston et al. 2000; Boraston et al. 2002; Blake et al. 2006).

Samples were cut from Sitka spruce (Picea sitchensis (Bong.) Carrière) trees grown at Kershope, Northumbria, UK and felled when 36 years old. Transverse sections were cut (20 $\mu \mathrm{m}$ thick) with a sliding microtome from the wood blocks (L: $30 \mathrm{~mm}, \mathrm{~T}: 5$ $\mathrm{mm}$, R: $50 \mathrm{~mm}$ ) after soaking in cold water for $30 \mathrm{~min}$. This ensured that no extraction of any wood components occurred during sample preparation.

The wood sections were incubated for $1 \mathrm{~h}$ at room temperature under gentle shaking with $200 \mu \mathrm{l}$ primary molecular probe solution dissolved in $800 \mu \mathrm{l} 3 \%$ milk powder in phosphate-buffered saline (PBS) (Jones et al. 1997). The liquid was removed and the wood sample was washed 3 times for $5 \mathrm{~min}$ with PBS under the same conditions. In case of his-tagged CBMs an additional labelling step using anti-mouse-His before antiIgG FITC application was needed as described by McCartney et al. (2004). Bound primary molecular probes were then labeled with the corresponding anti-IgG FITC (Sigma), using $750 \mu \mathrm{l}$ of a 1:100 dilution in 3\% milk powder in PBS. Incubation lasted 1 $\mathrm{h}$ at room temperature under gentle shaking in the dark. The samples were again washed 3 times for $5 \mathrm{~min}$ in PBS. Finally the wood sections were mounted onto microscope slides in the presence of Citifluor anti-fade reagent (Agar Scientific). The labeled samples were examined with an Olympus BH6 microscope equipped with epifluoresc-

Altaner et al. (2007). "In Situ Detection of Polysaccharides," BioResources 2(2), 284-295. 285 
ence irradiation. Alternatively, a Zeiss CLSM510-UV microscope, fitted with a $488 \mathrm{~nm}$ laser and 505-550 nm band-pass filter, was used to acquire higher resolution images by confocal laser scanning microscopy. Bright-field images were collected with a transmitted light detector.

\section{RESULTS AND DISCUSSION}

\section{Cellulose}

Three different CBMs directed to cellulose were tested for their potential to bind to untreated wood. Whereas the CBM belonging to family $3 \mathrm{a}$ binds to crystalline cellulose, the CBMs belonging to family 28 and 17 have an affinity for amorphous cellulose (McCartney et al. 2004; Blake et al. 2006). Figure 1 shows equivalent crosssections containing a band of compression wood $(\mathrm{CW})$ that appeared brighter in the control than the neighbouring normal wood (NW).

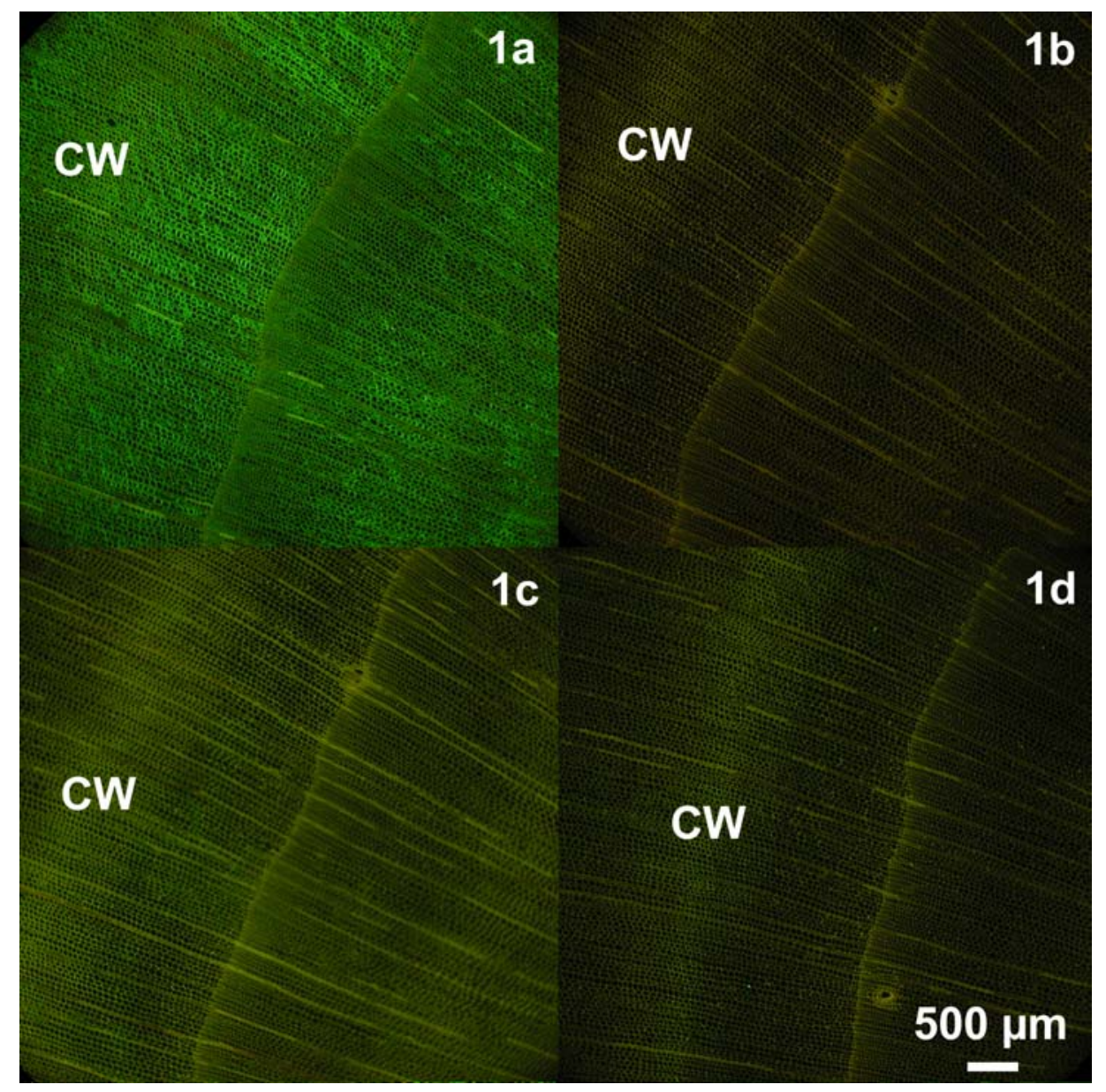

Fig. 1. Equivalent unextracted Sitka spruce cross-sections containing a compression wood (CW) band incubated with CBM3a (a), control (without primary molecular probe) (b), CBM17 (c) and CBM28 (d). The true colour images were obtained with a fluorescence-microscope. 
The autofluorescence of the wood cell wall in the control can be attributed to lignin present in wood (Donaldson et al. 1999) (Fig. 1b). Despite the yellowish lignin auto-fluorescence, the bright green fluorescence of antibody-linked FITC could be clearly identified. CBM3a, binding to crystalline cellulose, strongly stained all wood types in the samples similarly (Fig. 1a). CBMs from families 17 and 28, having an affinity to amorphous cellulose, displayed a differential reaction, with CBM17 binding to ray cells and CW (Fig. 1c), whereas CBM28 (Fig. 1d) was almost equivalent to the control (Fig. 1b), with a negligible amount of binding. The obvious difference in affinity to xylem tissue of the CBMs, showing a much stronger binding of the CBM recognising crystalline cellulose, is comparable with literature reports of other species, e.g. tobacco stems (Blake et al. 2006).

Due to the differences in the affinity of the individual CBMs towards their ligands, it is not possible to draw conclusions from the staining intensity on the amount of the corresponding cellulose types in the cell walls. If it is assumed that all the molecular probes bind only to cellulose of one form or another, then this premise leads to the interpretation that whereas crystalline cellulose is abundantly present in all cell types, amorphous cellulose is predominately present in ray cells and $\mathrm{CW}$ tracheids. However, it has to be mentioned that the staining for $\mathrm{CW}$ may be due to the presence of $\beta$-1-3-glucan (callose) structures, which are present in severe CW (Hoffmann and Timell 1972, Fig. 4), since recognition of callose by this CBM has been reported (Boraston et al. 2000; Boraston et al. 2002).

Apart from the aforementioned factors, affinity and selectivity, the accessibility of the ligands can have a significant influence on the results of immunolabelling studies. Indeed variations in the accessibility of the polymers have been exploited to visualise damages in spruce pulp fibres using a CBM (Hildén et al. 2003). In the case of our study, differences in accessibility between NW and CW are not expected due to sample preparation. First, this is because the tissue types are present within the same sections, ruling out an influence of the microtome knife. Secondly although variations in the microfibril angle could result in additional variations in the accessibility on the tissue level due to alterations in the surface roughness of the section, this seems unlikely, since we used juvenile wood which like CW has a high microfibril angle. At the cell wall level we found indications that CBM3a bound more strongly to the inner and outer secondary cell wall layers (data not shown). This is consistent with the findings of Hildén et al. (2003).

Solid-state NMR spectroscopy (Hult et al. 2000; Andersson et al. 2004; Newman 2004) and x-ray diffraction (Andersson et al. 2003; 2004; Thygesen et al. 2005) have been used to study the cellulose structure in wood. X-ray diffraction yields data on the crystallinity index and size cellulose crystals. Solid-state NMR spectroscopy gives insights into the various forms of crystalline cellulose (i.e. I $\alpha$, I $\beta$, and para-crystalline), as well as the amount of accessible and inaccessible surface chains. Based on the assumption that CBMs bind selectively to individual forms of cellulose, it can be expected that they posses the potential to validate the above-mentioned methods for the analysis of cellulose structures. Especially with respect to the more disordered cellulose structures, which are inaccessible to x-ray diffraction, CBMs promise to be powerful in gaining information. This is because the affinity of CBMs towards cellulose can be 
expected not only to be dependent on the crystallinity index, but also the size of the individual fibril aggregates. Furthermore the application of CBMs has the potential to increase the resolution from the tissue level to the level of the individual cell wall layers. The average cellulose crystallinity for Norway spruce (Picea abies (L.) Karst.), Scots pine (Pinus sylvestris L.), and Radiata pine (Pinus radiata) was reported to be slightly above $50 \%$. This value is fairly constant for the individual wood types (namely juvenile wood, mature wood, early wood, late wood, opposite wood, and CW) with the tendency to higher values for slow grown tracheids (Newman 2004). To the best of our knowledge, information on the crystal size of cellulose in conifers is only available on NW for Norway spruce and Scots pine (Andersson et al. 2004). Although this data does not show any difference between the two species it cannot be ruled out that a difference between individual wood tissues, in particular for $\mathrm{CW}$, does exist. Indeed increased lateral dimensions of the cellulose crystals in tension wood compared to NW have been reported (Washusen and Evans 2001). Hult et al. (2000) found indications of an unique cellulose structure in CW by solid-state NMR spectroscopy. A higher proportion of paracrystalline cellulose in $\mathrm{CW}$ was accompanied by an increased amount of accessible cellulose fibril surface. These results are consistent with a selective staining of CW by CBM17 as seen in Figure 1c. To our knowledge no data on the cellulose structure of parenchymatic ray cells of conifers exists.

\section{Mannan}

In native wood, mannans were detected by the antibody binding to linear $\beta-1-4-$ mannan structures. Staining was consistent for all examined wood types, namely early wood, late wood, NW, and CW, although cells forming resin channels were less stained than the surrounding tracheids (Fig. 2).

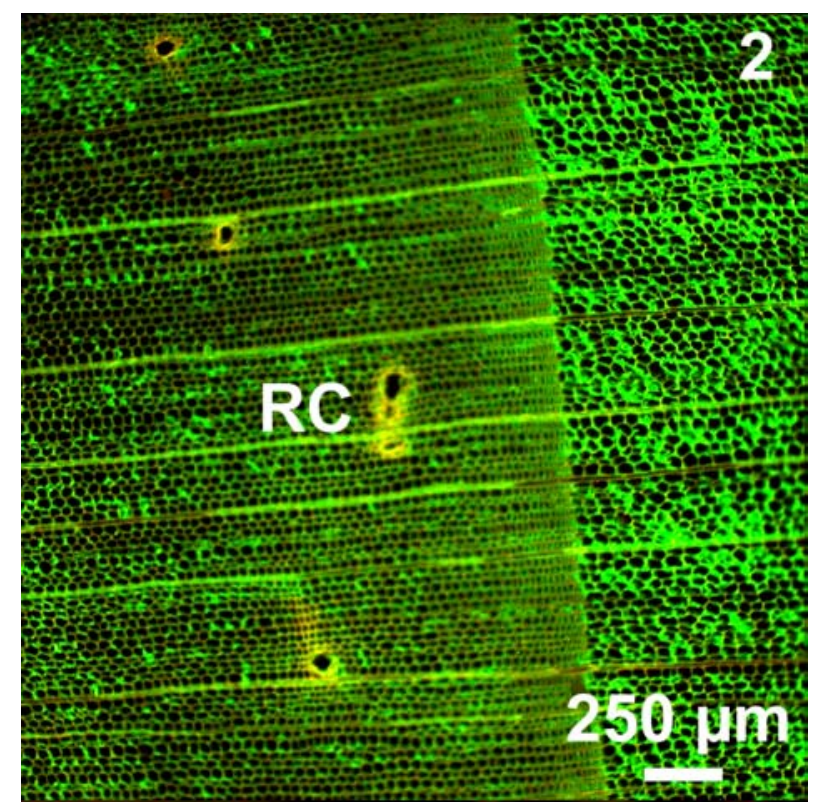

Fig. 2. Unextracted Sitka spruce cross-sections labelled for linear $\beta-1-4-m a n n a n$ structures including resin channels (RC). The images were obtained with a fluorescence-microscope and contrast enhanced. 
It is unlikely that the reduced labelling of the resin channel forming cells is caused by a decreased accessibility of the $\beta$-1-4-mannan antibody to its epitope due to a high resin content of the cells, since labelling with LM11 for $\beta$-1-4-xylan (Fig. 3) showed the opposite effect. On the cellular level immunofluorescence labelling indicated differences in the mannan content between the individual cell wall layers (data not shown). Electron microscopy in combination with immuno-(gold)labelling is required to confirm this.

\section{Xylan}

Strong binding of the anti- $\beta-1-4-x y l a n$ LM11 antibody was found for all wood types. Cells forming the resin channels showed a stronger fluorescence than the surrounding tissue (Fig. 3). Labelling of cells forming resin channels clearly differed for xylan and mannan. A reduced mannan content (Fig. 2) seemed to be accompanied by an increased xylan content of those cells (Fig. 3). Binding of anti- $\beta-1-4-x y l a n$ antibody to wood resins seemed unlikely, due to their different chemical structures. As in the case of mannan immunofluorescence, labelling indicated differences in the xylan content between the individual cell wall layers (data not shown), but higher resolution microscopy is required to draw clear conclusions.

To the best of our knowledge no experiments have been reported which investigate the chemical composition of epithelial cell walls of wood. Studies on the chemical composition of resin ducts have focused on the cell contents and not the cell walls (Nagy et al. 2000). A deviation in the chemical composition of those cell walls from ordinary tracheids would support the distinctive biological function of resin channels in either facilitated secretion of the resin or increased resistance against microbial attack.

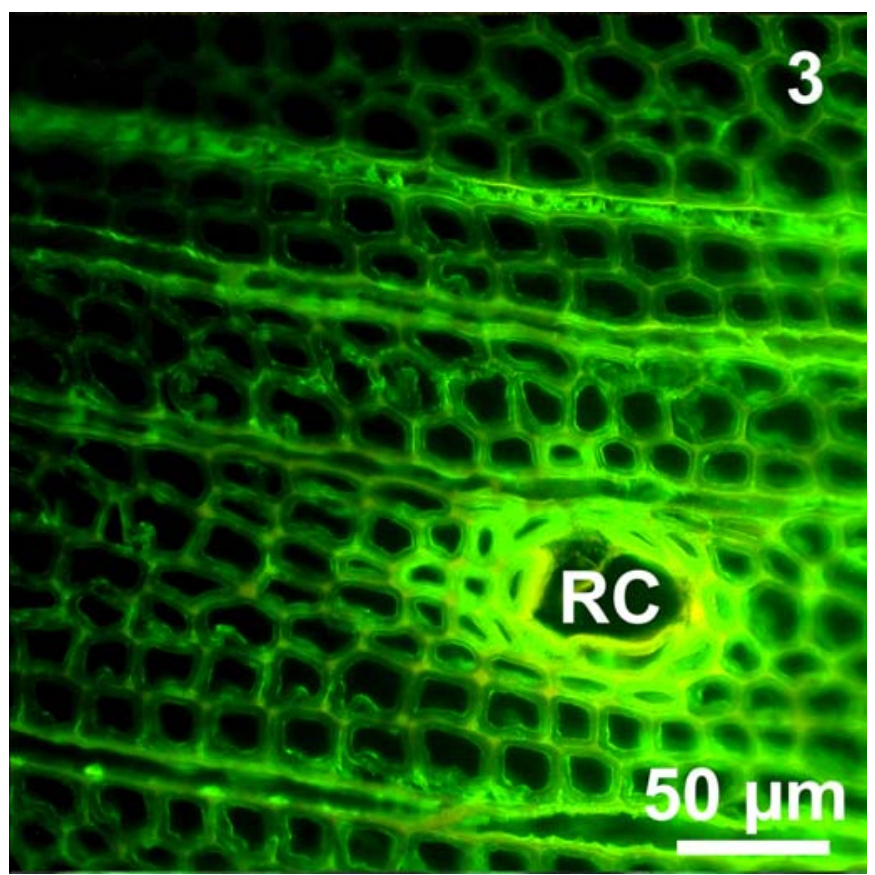

Fig. 3. Unextracted Sitka spruce cross-sections labelled for linear $\beta-1-4-x y l a n$ structures using LM11 including resin channels (RC). The images were obtained with a fluorescence-microscope and contrast enhanced. 


\section{Callose}

Callose was detected in severe CW. A patchy staining pattern of the $\beta$-1-3-glucan monoclonal antibody was observed on cell wall surfaces towards the lumen in $\mathrm{CW}$ tracheids (Fig. 4). Hoffmann and Timell (1972) identified small amounts of callose in severe CW by classical wet-chemical wood analysis. Furthermore Waterkeyn et al. (1982) as well as Włoch and Hejnowicz (1983) located $\beta$-1-3-glucan structures in or between the helical cavities of severe $\mathrm{CW}$ tracheids with aniline blue staining. These findings are consistent with observations made using the $\beta$-1-3-glucan binding monoclonal antibody.

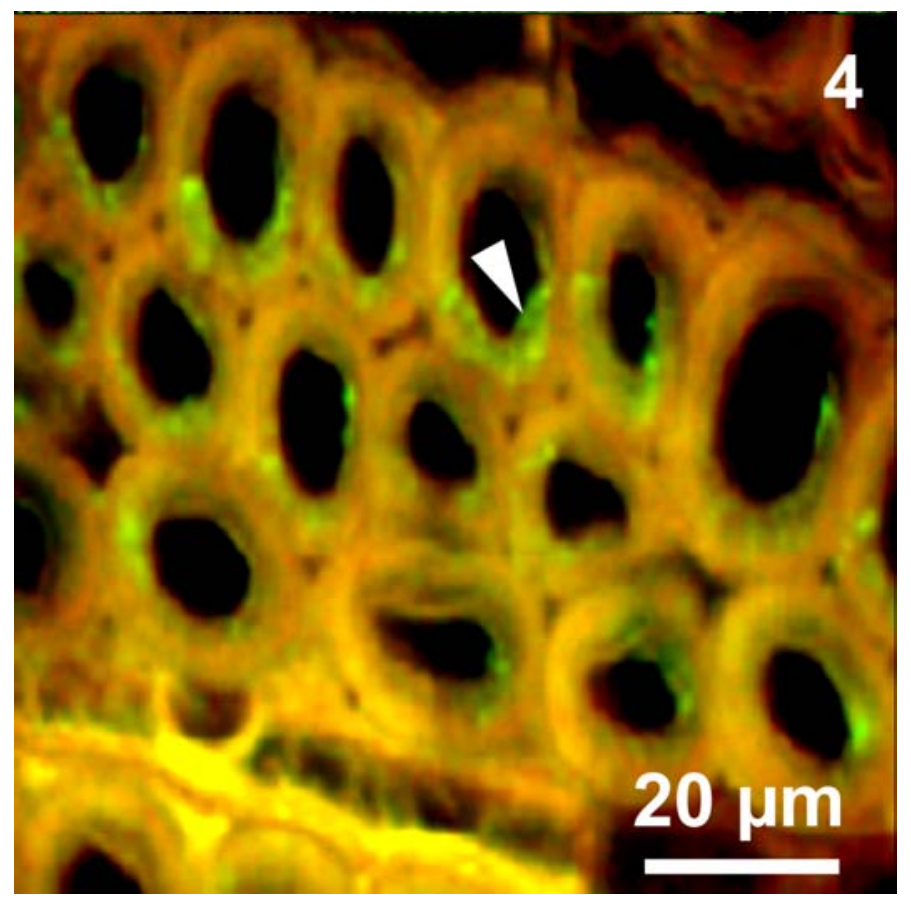

Fig. 4. Unextracted severe CW Sitka spruce cross-section labelled for $\beta-1-3-g l u c a n$ (callose) structures. Arrow indicates callose in or between the helical cavities. The image was obtained with a fluorescence-microscope and contrast enhanced.

\section{Arabinan}

A monoclonal antibody to $\alpha-1-5$-arabinan indicated that this polysaccharide structure was located in the linings of intercellular spaces between tracheids of severe $\mathrm{CW}$ and in the walls of parenchymatic ray cells (Fig. 5). Ermel et al. (2000) detected a constant decrease of $\alpha-1-5$-arabinan in differentiating poplar tissue from phloem to xylem, indicating its importance during cell differentiation. Whereas these authors were not able to obtain information on the distribution of LM6 epitope in poplar wood cell walls by electron microscopy, primary cell walls showed an absence or reduced abundance of $\alpha-1-5$-arabinan structures in the middle lamella and cell corners compared to the homogenously labelled primary cell wall (Serpe et al. 2002; Guillemin et al. 2005). Because wood contains only minor amounts of arabinose (Côté et al. 1968) it seems likely that the $\alpha-1-5$-arabinan structures are concentrated in the primary wall. 
Therefore one might speculate that Sitka spruce shows active control of cell separation when forming CW, by digestion of the middle lamella and exposing the $\alpha-1-5$ arabinan containing primary wall.

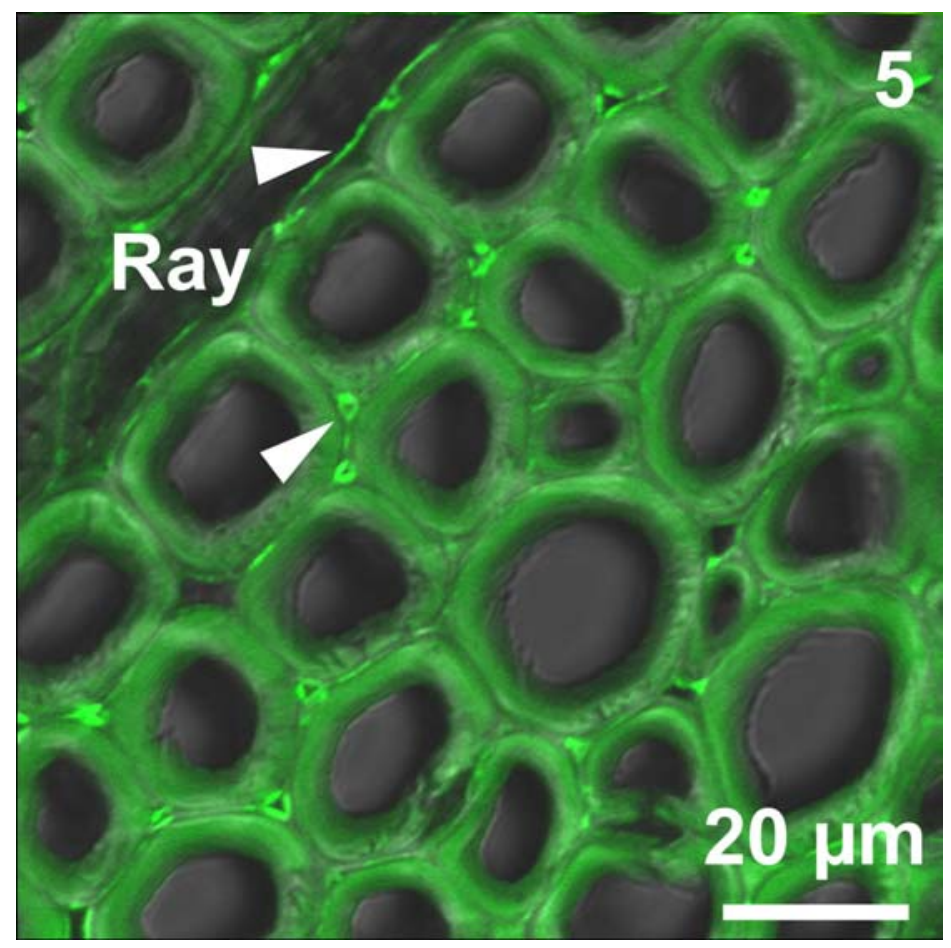

Fig. 5. Confocal laser scanning image of an unextracted severe CW Sitka spruce cross-section labelled for $\alpha-1-5$-arabinan structures using LM6. Bright field (a) and florescence signal (b). Arrows indicates arabinan lining the intercellular spaces between the tracheids in severe $\mathrm{CW}$ and in parenchymatic ray cells.

\section{CONCLUSIONS}

A wide range molecular probes (monoclonal antibodies and cellulose-directed recombinant his-tagged forms of CBMs) have proven to yield information on the distribution of cell wall polysaccharides in untreated wood tissue. Fluorescence labelling revealed differences in the chemical composition of wood on the tissue level. Resin channel forming cells exhibited a decreased mannan and an increased xylan content compared to the surrounding tracheids. CBMs directed to amorphous cellulose bound more intensively to ray cells and $\mathrm{CW}$ tracheids than normal wood tracheids. On the cellular level this technique indicated clear structures for $\alpha-1-5$-arabinan and callose. While in severe CW $\alpha-1-5$-arabinan is located in the intercellular spaces, callose is found towards the cell lumen. For the other molecular probes only indications of variable abundance of the corresponding epitopes in the different cell wall layers were found. Electron microscopy in conjunction with immuno-(gold) labelling would be needed to obtain images of the necessary resolution to provide unambiguous information on their distribution within the individual cell wall layers. 


\section{ACKNOWLEDGMENTS}

We thank Harry Gilbert (University of Newcastle Upon Tyne) for CBMs, S. Mochan and B. Gardiner (NRS Forest Research UK) for the provision of timber, A. Hapca (Napier University) for support with sample sectioning, S. Marcus for the help with the antibody labelling, M. Blatt (University of Glasgow) for granting access to a confocal laser scanning microscope and SHEFC for financial support.

\section{REFERENCES CITED}

Altaner, C., Hapca, A., Knox, J. P., and Jarvis, M. C. (2007). “Antibody labelling of galactan in Sitka spruce (Picea sitchensis (Bong.) Carrière)," Holzforschung. 61, 311316.

Andersson, S., Serimaa, R., Paakkari, T., Saranpää, P., and Pesonen, E. (2003). "Crystallinity of wood and the size of cellulose crystallites in Norway spruce (Picea abies)," J. Wood Sci. 49, 531-537.

Andersson, S., Wikberg, H., Pesonen, E., Maunu, S. L., and Serimaa, R. (2004). "Studies of crystallinity of Scots pine and Norway spruce cellulose," Trees. 18, 346-353.

Baba, K., Sone, Y., Kaku, H., Misaki, A., Shibuya, N., and Itoh, T. (1994). "Localization of hemicelluloses in the cell-walls of some woody-plants using immonugold electronmicroscopy," Holzforschung 48, 297-300.

Blake, A. W., McCartney, L., Flint, J. E., Bolam, D. N., Boraston, A. B., Gilbert, H. J., and Knox, J. P. (2006). "Understanding the biological rationale for the diversity of cellulose-directed carbohydrate-binding modules in prokaryotic enzymes," J. Biol. Chem. 281, 29321-29329.

Boraston, A. B., Chiu, P., Warren, R. A. J., and Kilburn, D. G. (2000). "Specificity and affinity of substrate binding by a family 17 carbohydrate-binding module from Clostridium cellulovorans cellulase 5A," Biochemistry 39, 11129-11136.

Boraston, A. B., Ghaffari, M., Warren, R. A. J., and Kilburn, D. G. (2002). "Identification and glucan-binding properties of a new carbohydrate-binding module family," Biochemical J. 361, 35-40.

Brändström, J., Joseleau, J. P., Cochaux, A., Giraud-Telme, N., and Ruel, K. (2005). "Ultrastructure of commercial recycled pulp fibers for the production of packaging paper," Holzforschung 59, 675-680.

Carrard, G., Koivula, A., Soderlund, H., and Beguin, P. (2000). “Cellulose-binding domains promote hydrolysis of different sites on crystalline cellulose," Proc. Nat. Acad. Sci. USA 97, 10342-10347.

Côté, W. A., Kutscha, N. P., Simson, B. W., and Timell, T. E. (1968). "Studies on compression wood. VI. Distribution of polysaccharides in cell wall of tracheids from compression wood of Balsam fir Abies balsamea (L) Mill," Tappi 51, 33-40.

Coutinho, P. M., and Henrissat, B. (1999). "Carbohydrate-active enzymes: an integrated database approach." In: Recent Advances in carbohydrate bioengineering. Eds. Gilbert, H. J., Davies, G., Henrissat, B., Svensson, B. The Royal Society of Chemistry, Cambridge. pp. 3-12. 
Dahlman, O., Jacobs, A., Liljenberg, A., and Olsson, A. I. (2000). "Analysis of carbohydrates in wood and pulps employing enzymatic hydrolysis and subsequent capillary zone electrophoresis," J. Chromatogr. A 891, 157-174.

Daniel, G., Filonova, L., Kallas, A. M., and Teeri, T. T. (2006). "Morphological and chemical characterisation of the G-layer in tension wood fibres of Populus tremula and Betula verrucosa: Labelling with cellulose-binding module CBM1(HjCel7A) and fluorescence and FE-SEM microscopy," Holzforschung 60, 618-624.

Din, N., Gilkes, N. R., Tekant, B., Miller, R. C., Warren, A. J., and Kilburn, D. G. (1991). "Non-hydrolytic disruption of cellulose fibers by the binding domain of a bacterial cellulase," Bio-Technol. 9, 1096-1099.

Donaldson, L. A., Singh, A. P., Yoshinaga, A., and Takabe, K. (1999). "Lignin distribution in mild compression wood of Pinus radiata," Can. J. Bot. 77, 41-50.

Dokken, K. M., Davis, L. C., and Marinkovic, N. S. (2005). "Use of infrared microspectro-scopy in plant growth and development,' Appl. Spectrosc. Rev. 40, 301326.

Duchesne, I., Takabe, K., and Daniel, G. (2003). "Ultrastructural localisation of glucomannan in kraft pulp fibres," Holzforschung 57, 62-68.

Ermel, F. F., Follet-Gueye, M. L., Cibert, C., Vian, B., Morvan, C., Catesson, A. M., and Goldberg, R. (2000). "Differential localization of arabinan and galactan side chains of rhamnogalacturonan I in cambial derivatives," Planta 210, 732-740.

Filonova, L., Kallas, A. M., Greffe, L., Johansson, G., Teeri, T. T., and Daniel, G. (2007). "Analysis of the surfaces of wood tissues and pulp fibers using carbohydrate-binding modules specific for crystalline cellulose and mannan," Biomacromolecules 8, 91-97.

Guglielmino, N., Liberman, M., Jauneau, A., Vian, B., Catesson, A. M., and Goldberg, R. (1997). "Pectin immunolocalization and calcium visualization in differentiating derivatives from poplar cambium," Protoplasma 199, 151-160.

Guillemin, F., Guillon, F., Bonnin, E., Devaux, M. F., Chevalier, T., Knox, J. P., Liners, F., and Thibault, J. F. (2005). "Distribution of pectic epitopes in cell walls of the sugar beet root," Planta 222, 355-371.

Hafrén, J. (2005). “Antibody-based assay for galacturonan deesterification on wood pulp fibers during bleaching, “ J. Wood Sci. 51, 655-658.

Hafrén, J., Daniel, G. (2003). "Distribution of methyl-esterified galacturonan in chemical and mechanical pulp fiber," J. Wood Sci. 49, 361-365.

Hildén, L., Daniel, G., and Johansson, G. (2003) "Use of a fluorescence labelled, carbohydrate-binding module from Phanerochaete chrysosporium Cel7D for studying wood cell wall ultrastructure,". Biotechnol. Lett. 25, 553-558.

Hoffmann, G. C., and Timell, T. E. (1972). "Polysaccharides in ray cells of compression wood of Red pine (Pinus resinosa)," Tappi 55, 871-873.

Hori, R., and Sugiyama, J. (2003). "A combined FT-IR microscopy and principal component analysis on softwood cell walls," Carbohydr. Polym. 52, 449-453.

Hult, E. L., Larsson, P. T., and Iversen, T. (2000). "A comparative CP/MAS C-13-NMR study of cellulose structure in spruce wood and kraft pulp," Cellulose 7, 35-55.

Jones, L., Seymour, G. B., and Knox, J. P. (1997) "Localization of pectic galactan in tomato cell walls using a monoclonal antibody specific to (1->4)-beta-D-galactan," Plant Physiol. 113, 1405-1412. 
Knox, J. P. (1997). "The use of antibodies to study the architecture and developmental regulation of plant cell walls." In: International review of cytology - a Survey of Cell Biology, Academic Press, San Diego, Vol. 171 pp. 79-120.

Lafarguette, F., Leple, J. C., Dejardin, A., Laurans, F., Costa, G., Lesage-Descauses, M. C., and Pilate, G. (2004). "Poplar genes encoding fasciclin-like arabinogalactan proteins are highly expressed in tension wood," New Phytologist 164, 107-121.

Lappalainen, A., Tenkanen, M., and Pere, J. (2004). "Specific antibodies for immunochemical detection of wood-derived hemicelluloses." In: Hemicelluloses: Science and technology, ACS, Washington. Vol. 864 pp. 140-156.

Maeda, Y., Awano, T., Takabe, K., and Fujita, M. (2000). "Immunolocalization of glucomannans in the cell wall of differentiating tracheids in Chamaecyparis obtuse," Protoplasma 213, 148-156.

McCartney, L., Blake, A. W., Flint, J., Bolam, D. N., Boraston, A. B., Gilbert, H. J., and Knox, J. P. (2006). "Differential recognition of plant cell walls by microbial xylanspecific carbohydrate-binding modules," Proc. Nat. Acad. Sci. USA 103, 4765-4770.

McCartney, L., Gilbert, H. J., Bolam, D. N., Boraston, A. B., and Knox, J. P. (2004). "Glycoside hydrolase carbohydrate-binding modules as molecular probes for the analysis of plant cell wall polymers," Anal. Biochem. 326, 49-54.

McCartney, L., Marcus, S. E., and Knox, J. P. (2005). "Monoclonal antibodies to plant cell wall xylans and arabinoxylans," J. Histochem. Cytochem. 53, 543-546.

Nagy, N. E., Franceschi, V. R., Solheim, H., Krekling, T., and Christiansen, E. (2000). "Wound-induced traumatic resin duct development in stems of Norway spruce (Pinaceae): Anatomy and cytochemical traits," Am. J. Bot. 87, 302-313.

Newman, R. H. (2004). "Homogeneity in cellulose crystallinity between samples of Pinus radiata wood," Holzforschung 58, 91-96.

Pranovich, A., Konn, J., and Holmbom, B. (2006). "Methodology for chemical microanalysis of wood." In: Proceedings of the 9th European Workshop on Lignocellulosics and Pulp (EWLP). University of Natural Resources and Applied Life Sciences (BOKU), Vienna. pp. 436-439.

Samuels, A. L., Rensing, K. H., Douglas, C. J., Mansfield, S. D., Dharmawardhana, D. P., and Ellis, B. E. (2002). "Cellular machinery of wood production: differentiation of secondary xylem in Pinus contorta var. latifolia," Planta 216, 72-82.

Serpe, M. D., Muir, A. J., and Driouich, A. (2002). "Immunolocalization of beta-Dglucans, pectins, and arabinogalactan-proteins during intrusive growth and elongation of nonarticulated laticifers in Asclepias speciosa Torr.," Planta 215,357-370.

Taylor, J. G., Haigler, C. H., Kilburn, D. G., and Blanton, R. L. (1996). "Detection of cellulose with improved specificity using laser-based instruments," Biotechnic \& Histochem. 71, 215-223.

Thygesen, A., Oddershede, J., Lilholt, H., Thomsen, A. B., and Ståhl, K. (2005). "On the determination of crystallinity and cellulose content in plant fibres," Cellulose 12, 563576.

Vreeland, V. (1970). "Localization of a cell wall polysaccharide in a Brown alga with labeled antibody,“ J. Histochem. Cytochem. 18, 371-373.

Washusen, R., and Evans, R. (2001). "The association between cellulose crystallite width and tension wood occurrence in Eucalyptus globules," Iawa J. 22, 235-243. 
Waterkeyn, L., Caeymaex, S., and Decamps, E. (1982). "Callose in compression wood tracheids of Pinus and Larix," Bull. Soc. R. Bot. Belg. 115, 149-155.

Willats, W. G. T., Marcus, S. E., Knox, J. P. (1998). "Generation of a monoclonal antibody specific to (1->5)-alpha-L-arabinan," Carbohydr. Res. 308, 149-152.

Włoch, W., and Hejnowicz, Z. (1983). "Location of Laricinan in Compression Wood Tracheids.” Acta Soc. Bot. Pol. 52, 201-203.

Article submitted: February 20, 2007; First round of revisions completed: April 2, 2007; Revised version received: May 5, 2007; Article accepted: May 10, 2007; Article published: May 25, 2007. 